\title{
Historicity of Texts and Textuality of History-On The Virginian From the Perspective of New Historicism*
}

\begin{abstract}
LIU Jie-xiu
Northeast Petroleum University, Daqing, China

The Virginian: A Horseman of the Plains (1902) has been considered as one of the masterpieces of American western novels for its successful depiction of cowboys and local customs, which earns Owen Wister the Father of Western fiction. The paper aims to reveal the relationship between The Virginian and its historical context by applying the doctrines of New Historicism: historicity of texts and textuality of history. By historicity of texts, it points out that the work is the emblem of disappearance of western frontier, and it symbolizes the union of the Wild West and the civilized east. By textuality of history, it detects the change of social class, the development of livestock industry and railway, and their influence on the work at the later part of 19th century.
\end{abstract}

Keywords: The Virginian, new historicism, text, history

\section{Introduction}

Owen Wister became well-known worldwide for his work The Virginian: A Horseman of the Plains (1902) (The Virginian hereinafter), which was considered as "one of masterpieces of American western fiction" (ZHU, 2010, p. 19) for its depiction of cowboys and local customs in American Wild West. After its publication, cowboy novels came to be one of the most American-characteristic genres. Setting in Wyoming the story centered on a "cowpuncher", who was named "the Virginian" for the place where he came from. The novel was created at the ending period of Westward Movement, which was an important historical event in American history, and described the special social condition and culture of American west around the 1880s. Analyzed from the perspective of New Historicism, the text would reveal its historicity and how history was mixed into text in its historical context.

\section{New Historicism}

New Historicism is a school of literary theory, which emerged in 1980s and became popular in 1990s. Stephan Greenblatt, a professor in University of California, first used the term "new historicism" in his introduction to The Power of Forms in the English Renaissance (1982). He often referred to the term as "cultural poetics" (Greenblatt \& Gunn, 2007, p. 26). Apart from Stephan Greenblatt, Hayden White, Louis Montrose, Jonathan Dollimore, Catherine Gallagher, and some other scholars have enriched it from different aspects.

\footnotetext{
* Foundation project: Supported by Heilongjiang Philosophy and Social Science Planning Research Program (Grant No: 12E090). LIU Jie-xiu, master, lecturer, School of Foreign Languages, Northeast Petroleum University.
} 
Theoretically, New Historicism was "promoted and inspired by Western Marxism and Poststructuralism simultaneously" (ZHU, 2010, p. 6). It inherited Marxist ideology from the chronological and diachronical perspectives, which were essential parts of its theoretical construction. Moreover, it was influenced greatly by Foucault's "power and discourse" (Brannigan, 1998, p. 59), Clifford Geertzian's “thick description” (Brannigan, 1998, p.103), Louis Althusser's ideology.

New Historicism aims to analyze text in context of history. Yet it differs from the critics between 1920 and 1950, who based their interpretation on a work's historical contents, such as social ideology, historical features, the author's life, and intentions of the work. Because they began to wonder whether the background about what happened can ever be really objectively known. New historicist critics views history "as a social science like anthropology and sociology, whereas old historicists tended to view history as literature's background" (Murfin, 1998, p. 35). It emphasizes on the interaction of text from such aspects as political power and cultural constructs. It aims to understand the text through its historical context and to understand cultural history through literature. Thus, New Historicism has its unique features in understanding history as well as text and unique conception of ideology and its interpretation of "historicity of texts and textuality of histories" (Greenblatt, 2005, p. 16).

\section{Historicity of Texts}

Post-structuralism and New Criticism stressed the independence of text, taking no account of biography, social conditions, and cultural factors. In their views, there was nothing outside of texts. Yet, New Historicism pointed out that particular text was to signify that it was not only socially produced but also socially productive- "that it is the product of work and that it performs work in the process of being written, enacted, or read" (CUI, 2007, p. 14). Hence, literary text had its historicity. Owen Wister (1860-1938) was born in a family of comfortable means and high social standing, in which his father was physician and his mother was a respected magazine writer. He graduated from Harvard in 1882. During 1884 to 1889, Wister spent several summers out in American west due to his health problem, and made his first trip to Wyoming in 1885 . He was fascinated with culture and terrain of the region. In 1891, he began to write stories and sketches of western life, which were published in Harper's Weekly. He spent nearly every summer living on ranches, in cow camps gathering material for the next 15 years. The rich life experience in American west provided Wister with colorful materials for the writing of The Virginian, which owned the peculiar artistic features in American history.

According to Louis Adrain Montrose, historicity of texts meant to "suggest the historical specificity, the social and material embedding, of all modes of writing - not only the texts that critics study but also the texts in which we study them" (Greenblatt \& Gunn, 2007, p. 209). New Historicism advocated the close relationship between text and society (or context), especially history when the text was produced. The Virginian was set in Wyoming of the 1880s, which was nearly the ending period of Westward Movement that began shortly after the first colonial settlements and continued until the beginning of the 20th century. When the Movement came to its ending period and an industrial country began to emerge, the western frontier came to disappear. The railroad began to emerge in the wild western region, and it was replacing the wagon slowing. Undoubtedly, the United States was developing from an agricultural society to an industrial society. According to Federick Jackson Turner, a prominent historian, "the disappearance of frontier was the milestone in American history" (Billington, 1975, p. 67) and it promoted the mixed nationality of Americans. The impending disappearance of frontier had great 
impact to the psychology of people, including Owen Wister. In his view, there was the surging passion in cowboys' bodies and true, noble temperament in their spirit. Therefore, Owen portrayed the character, the Virginian, who was brave, kind, and dependent with extraordinary insight. Such a figure was regarded as the representative of frontiersmen. Though the geographical frontier was disappearing with the development of society, people still worshiped such hero as the Virginian. As Inge (1989) pointed out that "The Virginian is emblem of the disappearance of the frontier in America" (p. 359).

By "historicity of texts", New Historicism emphasized that literary study should be reverted to the whole cultural study. The cowboy's image had great impact on Americans' temperament. "The West, not the East, was where distinctively American characteristics emerged. This produced a new type of citizen—one with the power to tame the wild and one upon whom the wild had conferred strength and individuality" (Taylor, 2008, p. 23). As each generation of pioneers moved 50 to 100 miles west, they abandoned useless European practices and ideas, and instead found new solutions to new problems created by their new environment. The personality of the Virginian represents the spirit of American frontiersman. "When you call me that, smile!" (Wister, 2010, p.11). Such optimistic attitude was typical among frontiersman. The Virginian was smart and courageous. On the road of shipping cattle to Chicago, he stopped other young guys turning to Rawhide, where gold was said to be found. Because of his outstanding work, he became the foreman, later the partner of Judge Henry. The Virginian's success in career aspired American citizens, which had mixed into the American dream: One was bound to succeed through personal efforts and struggle.

The love story and marriage of The Virginian with Mary Stark Wood had its special historical implications. The unnamed cowman had free, uncivilized life, without fixed abode in the Wild West. Yet Mary Stark Wood had been brought up in a civilized aristocratic eastern family. She was hired as a teacher in Bear Creek, which signified she was bringing civilized knowledge to the west. The two young people had lots of differences on the ideology. When Wood came to know that the Virginian executed his friend Steve and the other cattle thief by hanging in the woods, she argued with him and insisted that the criminal should be punished according to law instead of lynch. Yet the cowboy said: “ ...In Wyoming the law has been letting our cattle thieves go for two years. The courts into whose hands we have put the law are not applying the law... So when your ordinary citizen sees that he has placed justice in a dead hand, he must take justice back into his own hands where it was before. This is not breaking the law; it is mending it" (Wister, 2010, p. 329). Wood began to understand the morality of westerners and accepted its law of life. Meanwhile, she provided such classic books as Remeo and Juliet (1595) to the Virginian so that he became civilized in some way as the easterners. Their communication signified the compromise between eastern culture and western culture, between civilization and wildness. The marriage between them was the union of American east and west, rural area and urban area, aristocrats and the public.

\section{Textuality of History}

By the textuality of histories, Montrose meant that people:

Have no access to a full and authentic past, a lived material existence, unmediated by the surviving textual traces of the society in question - traces whose survival we cannot assume to be merely contingent but must rather presume to be at least partially consequent upon complex and subtle social process of preservation and effacement. (Greenblatt \& Gunn, 2007, p. 331) 
History could not be guaranteed objective since it was narrated by human being, who was impossiblely objective in the narration all the time. Since history was mostly recorded in the form of narration, historians could access history in the form of textuality as well. The Virginian revealed the peculiar history of Wyoming during the 1880 s. Moreover some historical events had been written into the text.

The most obvious event was the change of social class. With the disappearance of frontier and the development of industry, monopoly capitalism was gradually formed, which led to the change in social class. The bourgeois was differentiated into three levels: monopoly capitalist class, old middle bourgeois, and new middle bourgeois. Owen Wister and his heroine Miss Wood were the representatives of old middle bourgeois, which was declining with the rise of monopoly capitalism in the later part of 19th century. "Just one year before she was to be presented to the world... fortune had turned her back upon the Woods" (Wister, 2010, p. 72). Meanwhile, the Woods stood for the eastern aristocrat as well. The text said: "True democracy and true aristocracy are one and the same thing". "Let the best man win. That is true democracy" (Wister, 2010, p. 113). The author connected "aristocrats" with "democracy", which showed the American eastern aristocrats and old middle bourgeois intended to change their economic and declining psychological state by means of democracy.

Moreover, the development of animal husbandry in Wyoming was recorded in the text as well. Wyoming was typical pasturing area among American western cities. In 1867, Union Pacific Railroad Company laid its tracks through the barren plains of Wyoming going through Cheyenne, which promoted the development of animal husbandry. Cheyenne was chosen as the capital in July of 1867 catering for the construction of railroads. The construction of the Union Pacific Railroad brought hopes of prosperity to the region. The population there grew rapidly. In 1868, some rancher drove cattle from Texas to plains of Cheyenne and sold beef to railway construction workers. Later more ranchers raised cattle in Laramie River Valley and nearby plains. The livestock industry was very prosperous during 1881 and 1885 . Cattle and beef were transported to the east by railroad. Such transportation was very important to the development of economy. In The Virginian, the hero shipped cattle to Chicago, which brought huge fortune to Judge Henry.

The construction of railway had great impact on Wyoming. People from all walks of life came to the plain by train: The heroine Mary Stark Wood and Uncle Hughey's new wife, the feminine representatives from the east, came to the west in search of freedom and new life by train. Drummer, missionary came as well. In addition to the increase in population, the merchandise from the east was flowing to the Wild West. The Virginian and I (the narrator) had "sardines, potted chicken and ham" (Wister, 2010, p. 36). The Virginian wore the wedding suit from the east as well. More importantly, cattle were transported to the east and European cities, which brought fortune to the west. As a result of its rapid development in economy and population, Wyoming became the 44th state of the United States, and it began its development of monopoly capitalism with other states together. Since "literary and non-literary texts circulated inseparably" (Wofreys, 2006, p. 176), it is necessary to understand history with the help of literary texts in order to see the culture and history in the historical texts.

\section{Conclusions}

According to New Historicism, one can "gain a more comprehensive understanding of literature by considering it in historical context while treating history itself as historically contingent on the present in which it 
is constructed" (Greenblatt, 2005, p. 2). Therefore, analysis of The Virginian in its historical context can disclose the relationship between its text and history.

The work was produced during the ending period of Westward Movement, when the western frontier came to disappear. Yet, the Virginian in the text continued frontier ideas and frontier values which were nurtured in the wilderness. In addition, the hero of the text became the protype of later cowboy fictions, for he was kind, brave, and courageous with great insight. To some extent, the spirit embodied by the Virginian was that of American frontier spirit originated and developed during the process of conquering the West. He became a cultural symbol that involved the commitment to the codes, laws with the virtues of frontiers: self-reliant, keeping optimistic, and daring to meet challenges. These were mixed into the characteristics of American people. In this sense, the text shaped the history. The influence of historical context on The Virginian can be easily found in its context, from the change of social class, the rise of livestock industry to the construction of railroad, and its impact on the economic development. Therefore, approaching The Virginian from the perspective of New Historicism would provide new viewpoints for its text and history.

\section{References}

Billington, A. R. (1975). America's frontier heritage. New Mexico: University of New Mexico Press.

Brannigan, J. (1998). New historicism and cultural materialism. New York: ST. Martain's press.

Colebrook, C. (1997). New literary histories. Manchester: Manchester University Press.

CUI, D. (2007). Re-evaluation of New Historicism (Unpublished Ph.D. dissertation at Northeast Normal University, China).

Freeman, Jr. C. (2002). Owen Wister-Brief life of a Western mythmaker: 1860-1938. Retrieved from http://harvardmagazine.com/2002/07/owen-wister.html

Greenblatt, S. (1982). The power of forms in the English Renaissance. NSW: Pilgrim Books.

Greenblatt, S. (2005). The greenblatt reader. Hoboken: Wiley-Blackwell.

Greenblatt, S., \& Gallagher, C. (2000). Practicing New Historicism. Chicago: University of Chicago Press.

Greenblatt, S., \& Gunn, G. (2007). Redrawing the boundaries: The transfromation of English and American literary studies. Beijing: Foreign Language Teaching and Research Press.

Hine, V. R., \& Faragher, M. J. (2000). The American west, a new interpretive history. New Haven: Yale University Press.

Inge, M. T. (1989). Handbook of American popular culture. Westport, Connecticut: Greenwood Pub Group.

LI, J. (2010). On the historical value of "The Virginian: A horseman of the plains". Collected Papers of History Studies, 1, 113-119.

Murfin, R., \& Ray, S. (1998). The Bedford glossary of critical and literary terms. Retrieved from $\mathrm{http} / / /$ bcs.bedfordstmartins.com/virtualit/poetry/critical_define/crit_newhist.html

Taylor, A. (2008). The old frontiers. The New Republic, May 7.

Wister, O. (2010). The Virginian. Shanghai: World Publishing Corporation.

Wolfreys, J. (2006). Introducing literary theories: A guide and glossary. Qingdao: China Ocean University Press \& Edinburgh University Press.

ZHU, L. (2010). Historicity of texts and the textuality of histories-On The Last of the Mohicans, The Luck of Roaring Camp and The Virginian by the approaches of New Historicism (Unpublished Master thesis at Guangxi Normal University, China). 